\title{
Papular Elastorrhexis: Case Report of a Rare Connective Tissue Naevus
}

\section{Prajwal Pudasaini ${ }^{1}$, Prashant Pudasaini ${ }^{2}$, Rabi Bhatta ${ }^{3}$}

${ }^{1}$ Gandaki Medical College, Pokhara; ${ }^{2}$ Kathamandu Medical College and Teaching Hospital, Sinamangal, Kathmandu; ${ }^{3}$ Universal College of Medical Sciences, Bharahawa

\begin{abstract}
Papular Elastorrhexis (PE) is a connective tissue naevus that presents with non-follicular, yellow or white oval papules(1$5 \mathrm{~mm}$ ), mostly on the proximal extremities and the trunk. It is diagnosed with good clinical acumen and histologically with fragmented or decreased dermal elastic fibers. PE is difficult for the clinicians to diagnose because of the rarity of the disease and non-specific presentation. Here we report a rare case of PE.
\end{abstract}

Key words: Papular Elastorrhexis; Connective Tissue Disease; Collagen, Elastin

\section{Introduction}

$\mathrm{P}$ apular Elastorrhexis (PE) a connective tissue naevus, is a rare sporadic condition which presents with multiple symmetrical asymptomatic non follicular, yellow or white oval papules (1-5mm), mostly on the proximal extremities and the trunk. ${ }^{1-3}$ There is no family history and no extracutaneous features in most cases of PE. ${ }^{1}$ It is diagnosed with good clinical acumen and histologically with fragmented or decreased dermal elastic fibers, with or without changes in collagen bundles in the dermis. ${ }^{4}$ PE is difficult for the clinicians to diagnose because of the rarity of the disease and non-specific presentation. ${ }^{1}$ Here we report a rare case of PE.

\section{Case Report}

A 25-year-old male, presented with lesions over back and upper arms for 2 years. Initially few, occasionally pruritic, small lesions were noted over trunk, which then spread over both upper arms. There was no history of any extracutaneous symptoms. There was no family history of similar lesion. On examination, multiple symmetrical skin colored-whitish, non-

Funding: No

Conflict of Interest: No

Address of Correspondence

Dr. Prajwal Pudasaini, MD

ORCID ID: 0000-0001-8549-625X

Sanchayakosh Bhawan Nayabazar, Prithivichowk, Pokhara, Nepal

Tel: 9849447266 Fax: +977- 61-550254,

E-mail: prajwalpudasaini@gmail.com follicular, papules measuring 2-5 $\mathrm{mm}$ were noted over back (shown in figure 1 and 2) and B/L upper arms (shown in figure 3). A provisional diagnosis of papular elastorrhexis was made and incisional biopsy was done. Histopathological examination (HPE) revealed thinned out epidermis lined by keratinized stratified squamous epithelium and hyalinized tissue in superficial dermis (shown in figure 4), dermis showed fragmented bits of collagenous tissue and few blood vessels (shown in figure 5). A final diagnosis of PE was made and patient was reassured for its benign nature.

\section{Discussion}

PE presents with multiple symmetrical asymptomatic non follicular yellow or white oval papules on the proximal extremities and the trunk. ${ }^{1-3}$ There is no family history and no extracutaneous features in most cases of PE. PE is difficult for the clinicians to diagnose because it is rare and has non-specific presentation. ${ }^{1}$ Fragmentation of elastic fibers in the dermis and rarefraction are important findings on

Date of Submission: $15^{\text {th }}$ July 2021

Date of Acceptance: $30^{\text {th }}$ August 2021

Date of Publication: $1^{\text {st }}$ October 2021

How to cite this article

Pudasaini P, Pudasaini P, Bhatta R. Papular Elastorrhexis: Case Report of a Rare Connective Tissue Naevus. NJDVL 2021;19(2):63-4. https://doi.org/10.3126/njdvl.v19i2.38465.

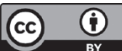

Licensed under CC BY 4.0 International License which permits use, distribution and reproduction in any medium, provided the original work is properly cited. 
histopathological examination of lesions. ${ }^{5}$ Specific treatment for papular elastorrhexis is not yet available. ${ }^{6}$ As $\mathrm{PE}$ is rare, diagnosis can be made with good clinical acumen and $\mathrm{HPE}^{1}{ }^{1}$ Overall prevalence of the disease can be estimated and clinical trials can be performed as there is no specific treatment till date and also benign nature of the disease can be explained to the patient. Definitive treatment of papular elastorrhexis is not yet available, and given the cosmetic complications of papular elastorrhexis anticipatory treatment can be done. ${ }^{6}$ Given the resource limitations of unavailability of electron microscope, definitive confirmation with presence of degenerated elastic tissue from disorganized fibroblast is usually not applicable in our setting. ${ }^{7}$ This limitation, highlights the importance of combined use of clinical and histopathological findings in the diagnosis of papular elastorrhexis and hence the timely counselling for expectant management. ${ }^{5,6}$

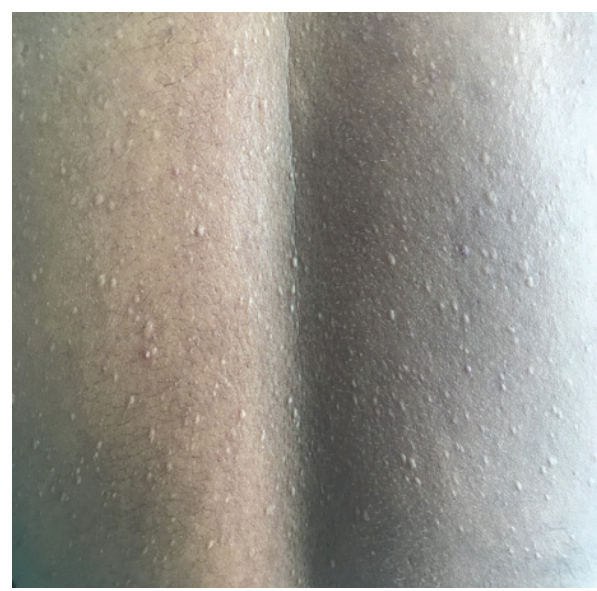

Figure 1: Multiple symmetrical skin colored non-follicular, papules over back

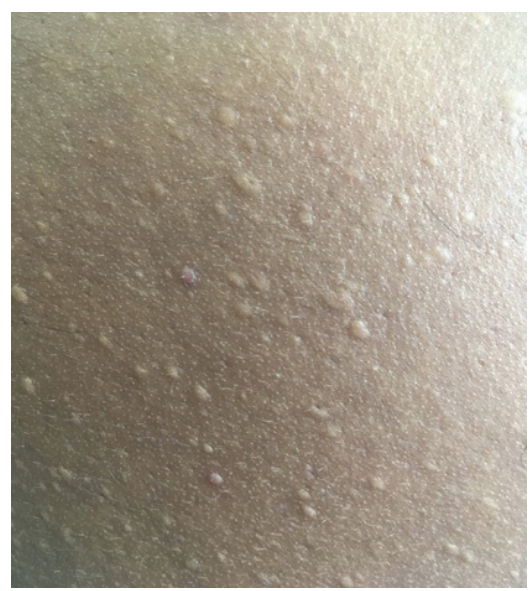

Figure 2: Multiple skin colored non-follicular, papules over back (zoomed in)

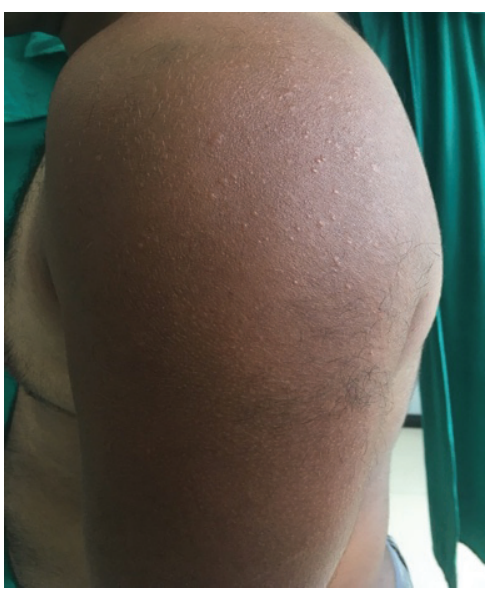

Figure 3: Multiple skin colored non-follicular, papules over upper left upper arm

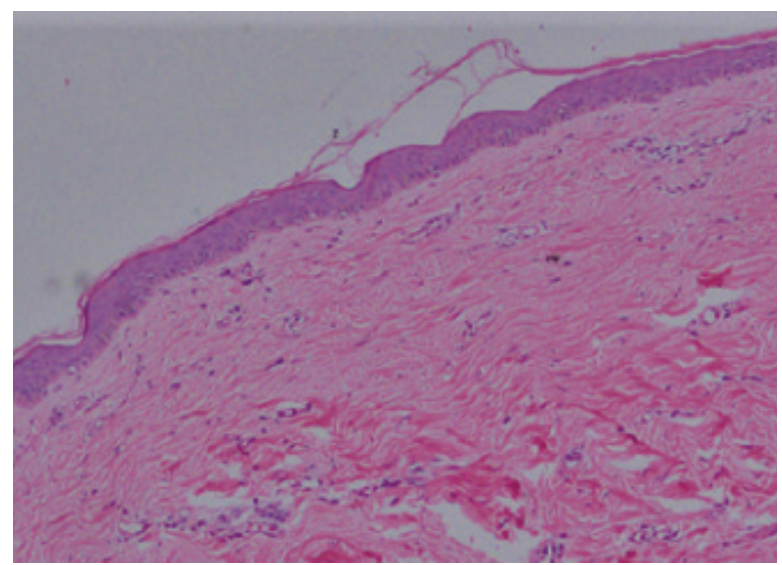

Figure 4: $\mathrm{H} \& \mathrm{E}$ section (scanning view) showing all the layers of epidermis with focal areas of hyalinized tissue in superficial dermis

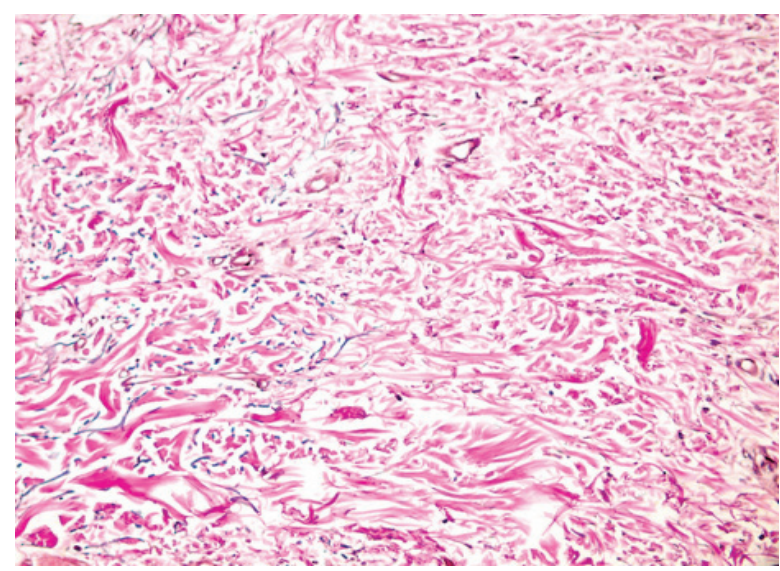

Figure 5: H \& E section (high power view) with fragmented bits of elastic tissue in dermis 


\section{Conclusion}

There can be variable nonspecific presentation of papular elastorrhexis, but the diagnostic modality (Verhoeff's Van Gieson stain) for the appropriate identification and timely intervention of the disease is not widely available. Thus, sensitive and specific diagnostic test needs to be employed at all level of health centers and hospitals to diagnose any patients with papular elastorrhexis. This will help to provide timely counselling about its benign nature and also look for progression to long term complications and therapeutic advancements.

\section{References}

1. Thomé E, Steglich R, Meotti C, Schwartz J, Boff A. Case for diagnosis. An. Bras. Dermatol. 2012;87(4):651-3. https://doi.org/10.1590/ S0365-05962012000400028

2. Şahin S, Durmaz E, Sezer E, Çetin E. Eruptive papular elastorrhexis of the face and scalp. J Am Acad Dermatol. 2013;69(5): e251-2. https://doi. org/10.1016/j.jaad.2013.05.027

3. Belmar Flores P, Cuevas J, Sánchez C, De Eusebio E, Vergara A. Papular elastorrhexis: an acquired disorder of elastic tissue. Eur J Dermatol. 2010;20(4):525-6. https://doi.org/10.1684/ ejd.2010.0979

4. Chu D, Goldbach H, Wanat K, Rubin A, Yan A, Treat J. A New Variant of Connective Tissue Nevus

with Elastorrhexis and Predilection for the Upper Chest. Pediatr Dermatol. 2014;32(4):518-21. https://doi.org/10.1111/pde.12456

5. Emre $S$, Yağlı $S$, Metin A, Kılıçarslan A, Demir Pektaş S. Şeyletiella Dermatiti. Turkderm. 2011;45(4):213-5. https://doi.org/10.4274/ turkderm. 37132

6. Luo D, Liu J, Chen M, Wang Z, Xie W. Papular elastorrhexis: report of four cases and review of literature. Arch Dermatol Res. 2014;307(2):99108. https://doi.org/10.1007/s00403-014-1509-z

7. Li S, Peng J, Yang $P$, Sheng $P$, Fan $Y$. Immunopathological and ultrastructural features in a case of papular elastorrhexis. J Dtsch Dermatol Ges.2017;15(2):212-214. https://doi. org/10.1111/ddg.12760 